\title{
PYRIDOXINE-DEPENDENT EPILEPSY INITIALLY RESPONSIVE TO PHENOBARBITAL
}

\author{
Jaime Lin', Katia Lin², Marcelo Rodrigues Masruha³, Luiz Celso Pereira Vilanova4
}

\begin{abstract}
Pyridoxine-dependent epilepsy is a rare autossomal recessive disorder characterized by recurrent seizures that are not controlled by anticonvulsant medications but remits after administration of pyridoxine. We report on a 30 day-old girl who presented with seizures during the first day of life, initially responsive to anticonvulsant therapy, which remitted within two weeks. Seizures were characterized as multifocal myoclonic jerks of upper and lower limbs associated with buccal-lingual oral movements and eyelid blinking. Laboratory and neuroimaging studies were normal. Electroencephalographic record demonstrated a abnormal background activity with high-voltage epileptic discharges and a burst-suppression pattern. The seizures ceased after oral administration of pyridoxine, but recurred after withdrawal, confirming the diagnosis.
\end{abstract}

KEY WORDS: pyridoxine, epilepsy, neurologic manifestations.

\begin{abstract}
Epilepsia por dependência de piridoxina inicialmente responsiva ao fenobarbital
RESUMO - A epilepsia por dependência de piridoxina é uma doença autossômica recessiva rara caracterizada por crises recorrentes refratárias a tratamento medicamentoso, mas que remitem após a administração de piridoxina. Relatamos o caso de menina de 30 dias de vida que iniciou crises convulsivas desde o primeiro dia de vida, inicialmente responsivas a tratamento com drogas anticonvulsivantes, mas que reiniciaram após a segunda semana de vida. As crises eram caracterizadas por movimentos clônicos erráticos de membros superiores e inferiores associados a movimentos oromandibulares e piscamentos. Exames laboratoriais e de neuroimagem foram normais. $O$ exame eletrencefalográfico evidenciou atividade de base desorganizada com descargas epilépticas de alta voltagem associadas a um padrão de surto-supressão. As crises cessaram após a administração de piridoxina e recorreram após a sua retirada, confirmando o diagnóstico.
\end{abstract}

PALAVRAS-CHAVE: piridoxina, epilepsia, manifestações neurológicas.

Pyridoxine dependency epilepsy (PDE), first recognized in $1954^{1}$, is a recessively inherited condition in which a child has epileptic seizures that are only controlled when pharmacological doses of pyridoxine are administered ${ }^{2-4}$. It is a rare condition, with few epidemiological studies available revealing a prevalence of one case in 687000 births in the United Kingdom 5 . In a more recent study in the Netherlands, a prevalence of one case in 396000 births was found ${ }^{6}$. This rarity limits the development of clinical trials that would facilitate its diagnosis or determine its optimal treatment regimen? ${ }^{7}$. Atypical presentations include lateonset PDE (after 19 months of life), seizures that initially respond to very small doses of pyridoxine but then require higher doses $^{8}$ and epileptic conditions that initially respond to anticonvulsants but then respond only to pyridoxine, challenging the diagno- sis?

Herein, we present on a definite case of PDE in a one month-old patient who was initially responsive to phenobarbital.

\section{CASE}

A 1 month-old girl was admitted to our hospital due to frequent seizures. She was born at term, from consanguineous parents (the parents were first degree cousins). Pregnancy was uneventful, and her mother did not use any medication, neither prescribed nor over-the-counter, or vitamin supplementation. Apgar scores were 9 and 9 after 1 and 5 minutes. Thirteen hours after birth, seizures were observed, being characterized by erratic myoclonic jerks of the upper and lower limbs associated with tonic horizontal deviation of the eyes to the right. The seizures lasted two minutes with spontaneous remission. Two hours later seizures recurred and $20 \mathrm{mg} / \mathrm{kg}$ phenobarbital was administered intravenously. Urine, blood and cerebrospinal fluid were collect-

Department of Neurology and Neurosurgery, Universidade Federal de São Paulo / Escola Paulista de Medicina (UNIFESP / EPM), São Paulo SP, Brasil: 'Resident-Physician, Division of Child Neurology; ${ }^{2}$ Associate-Physician, Epilepsy Research and Treatment Unit, ${ }^{3}$ Associate-Physician, Division of Child Neurology; ${ }^{4}$ Professor and Chairman, Division of Child Neurology.

Received 5 March 2007, received in final form 12 June 2007. Accepted 15 August 2007.

Dr. Jaime Lin - Avenida Dr. Altino Arantes 742 / 84 - 04042-003 São Paulo SP - Brasil. E-mail: linjaime@yahoo.com 
ed for metabolic analysis with normal results. The seizures persisted with gradually decreasing frequency and, after ten days, the patient was discharged with prescription of $5 \mathrm{mg} /$ $\mathrm{kg} /$ day of phenobarbital. No further seizures were observed for the next 15 days and at the day 26 the patient presented persistent episodes of seizures. At 29 days of life, the patient was admitted to our hospital for investigation. Physical and neurological examination of the infant revealed absence of grasp reflex, global hipotonia and hyperactivity of patellar reflexes with clonus at the feet. The seizures were characterized by myoclonic movements of upper and lower limbs, mainly on the left side of the body associated with tonic horizontal deviation of the eyes, eyelid blinking and oral movements. Each episode lasted for about 3 minutes with a high frequency during the day. Computed tomography (CT) scan and magnetic resonance imaging (MRI) of the brain were normal as well as complete blood count, serum biochemistry, urinalysis and cerebrospinal fluid analysis. Electroencephalogram (EEG) revealed an irregular and discontinuous background activity with high-voltage spikes and a burst-supression pattern (Fig $1 \mathrm{~A}$ ). Also, one electroclinical seizure consisting of multifocal myoclonic jerks of upper and lower limbs lateralized to the left, with tonic eye and head deviation to the right, eyelid blinking and oromandibular movements, associated with lateralized highvoltage electrographic seizure activity (Fig 1B).

While the diagnostic procedures were performed, a therapeutic trial with pyridoxine at $50 \mathrm{mg} /$ day was administered orally due to her clinical history of seizures starting at first day of life without any apparent cause. Approximately 12 hours after the oral administration of pyridoxine the seizures ceased and the patient became seizure free for a week. At the end of the first week, the patient stopped the medication with recurrence of seizures ten hours later. Then, pyridoxine was restarted orally with remission of seizures, and the patient remained seizure free with improvement of the EEG pattern (Fig 2).

One week after seizure control with oral administration of pyridoxine, phenobarbital was gradually removed and the patient was discharged from the hospital. The patient is currently seizure-free after six month of follow-up receiving pyridoxine at a dose of $200 \mathrm{mg}$ per day as a single therapy, and her last EEG resulted without abnormalities.

The Ethics Committee of the hospital approved the study and informed consent was obtained from the parents.

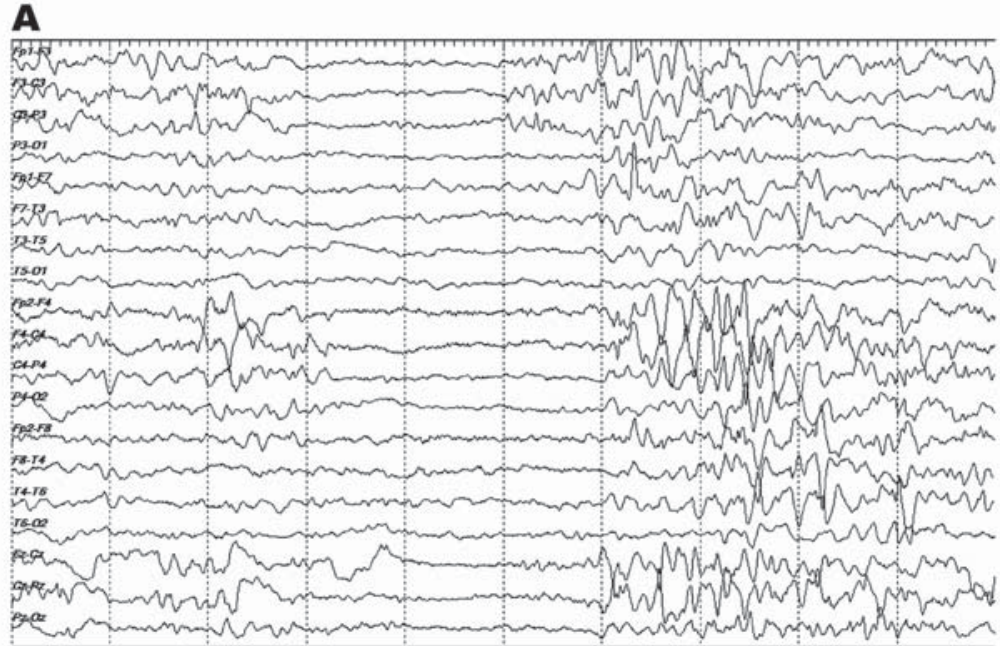

B

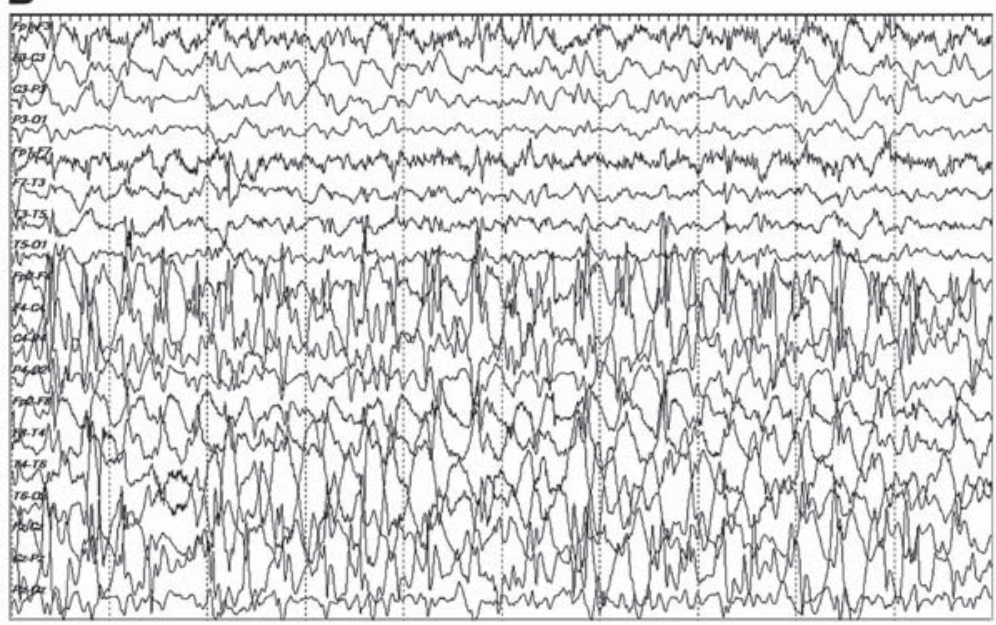

Fig 1. (A) Sleep EEG with burst-suppression pattern. (B) High-voltage eletrographic seizure activity consisting of spike and polyspike-wave complexes lateralized to the right cerebral hemisphere.

Sensibility $=10 \mu \mathrm{V}$, time constant $=0.1 \mathrm{~S}$, high frequency filter $=35 \mathrm{~Hz}$ 


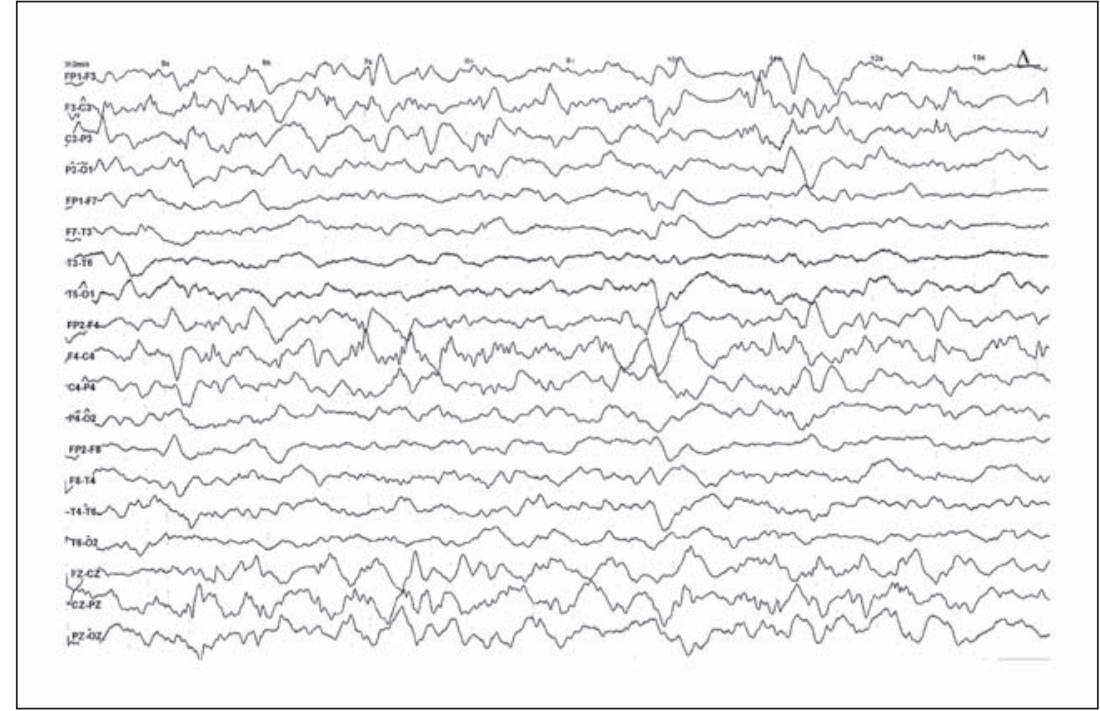

Fig 2. After treatment, sleep EEG with remission of the burst-suppression pattern.

Sensibility $=10 \mu \mathrm{V}$, time constant $=0.1 \mathrm{~S}$, high frequency filter $=35 \mathrm{~Hz}$

\section{DISCUSSION}

The typical clinical presentation of PDE consists of epileptic seizures beginning in the first few days of life (usually the first 24 to 48 hours), which are totally unresponsive to any conventional drug treatment. Once pyridoxine is administered they cease completely ${ }^{2-4,7}$. Several seizure types may occur and usually become increasingly frequent and severe until pyridoxine is started. In retrospect, mothers of affected infants may report episodes of unusual rhythmic intrauterine movements. Although intrauterine seizures are very uncommon, this is one of the few disorders in which they may occur ${ }^{2-4,7}$. Other features may be present: some babies with early-onset seizures also develop encephalopathy, vomiting and breathing difficulties.

Atypical cases, however, have been reported such as late-onset PDE starting after 19 months of life, seizures that initially respond to very small doses of pyridoxine but then later require pharmacological doses ${ }^{8}$ and epileptic conditions that initially respond to anticonvulsants but after a certain period of time respond only to pyridoxine, challenging its diagnosis ${ }^{9}$.

In this case, seizures started in the first hours of life, with myoclonic jerks of the limbs initialy responsive to usual doses of phenobarbital leading to a delay in the diagnosis.

PDE may be categorized in definite cases, defined as neonates, infants or young children with recurrent (two or more) seizures of any type that cease within seven days of the administration of oral pyridoxine or within 30 minutes of intravenous pyridoxine, that recur when pyridoxine supplementation is withdrawn, and than cease again when pyridoxine is restarted; and in possible cases, defined as above but without an attempt to withdrawn pyridoxine. Any recurrence of seizures while receiving pyridoxine constitutes an exclusion criterion, unless the recurrence occurs during a febrile illness 5 .

In our patient, the pyridoxine dependency was defined after an abrupt interruption in the administration of pyridoxine with recurrence of the seizures and its improvement after the reintroduction of pyridoxine.

Subsidiary exams such as brain imaging reveals a variety of abnormalities. Some neonatal-onset PDE ultrasound scans demonstrates apparent cysts adjacent to the lateral ventricles in the brain (similar cysts are seen in some metabolic conditions such as organic acidemias). The most typical structural abnormality identified by CT and/or MRI scans is hypoplasia of the posterior part of the corpus callosum and cerebellar hypoplasia ${ }^{5}$. None of these abnormalities were found in our patient.

Electroencephalographic findings can be, as well, very heterogeneous, with abnormal background activity, no sleep organization, discontinuous EEG with suppression burst-like pattern and spike and polyspike foci ${ }^{9}$. In our patient, EEG showed a discontinuous suppression burst-like pattern which disappeared after a therapeutic trial with pyridoxine.

Based on the seizure's fast response to pyridoxine administration, a diagnostic test using continuous EEG recording was developed. According to this test, patients with PDE would present an immediate improvement of the EEG pattern after the endovenous administration of pyridoxine ${ }^{9}$. The dose of pyridox- 
ine required in this test is not well established and there are reports of testing doses of pyridoxine that resulted not only in cessation of clinical seizures but also in prolonged depression of neurological and respiratory functions ${ }^{9}$.

In our patient, endovenous administration pyridoxine diagnostic test was not performed since its intravenous formulation was not available at that time.

The underlying pathophysiology of this condition remains unknown, pyridoxine dependent seizures seem to be caused by the deficiency of cerebral gamma-aminobutyric acid (GABA), a major inhibitory neurotransmitter of the central nervous system. Pyridoxal phosphate, the active metabolite of pyridoxine, is the coenzyme of glutamate decarboxylase, the rate-limiting enzyme for the production of GABA from glutamate ${ }^{9}$. However laboratory and genetic studies are still inconclusive?.

Although complementary exams can aid in its diagnosis, there is not any specific test for this condition. The only way to confirm its diagnosis is through a formal trial of withdrawal. The other certainty in this disorder is that pyridoxine has to be continued for life $e^{1-5,8,9}$.

The maintenance treatment dose varies widely from 2 to $300 \mathrm{mg} /$ day with a daily dose of $200 \mathrm{mg}$ orally being mostly recommended. No toxicity or side effects were noticed with this dosage $\mathrm{e}^{1-5,8,9}$. It is also recommended that pregnant women who previously gave birth to a child with PDE should receive $50-100 \mathrm{mg} /$ day of pyridoxine during the final half of gestation ${ }^{3}$.

Due to its rarity and in the absence of specific biochemical tests the diagnosis of PDE is not always easy. This entity is an obligatory differential diagnosis in any children (younger than three years old) with early onset intractable seizures or status epilepticus, since there is a possibility of treatment, which may affect its outcome.

\section{REFERENCES}

1. Hunt AD, Stokes J, Wallace MD, McCrory W, Stroud HH. Pyridoxine dependency: report of a case of intractable convulsions in an infant controlled by pyridoxine. Pediatrics 1954;13:140-145.

2. Gospe SM Jr. Pyridoxine-dependent seizures: findings from recent studies pose new questions. Pediatr Neurol 2002;26:181-185.

3. Baxter P. Pyridoxine-dependent seizures: a clinical and biochemical conundrum. Biochim Biophys Acta 2003;1647:36-41.

4. Gospe SM Jr. Current perspectives on pyridoxine-dependent seizures. J Pediatr 1998;132:919-923.

5. Baxter P. Epidemiology of pyridoxine dependent and pyridoxine responsive seizures in the UK. Arch Dis Child 1999;81:431-433.

6. Been JV, Bok LA, Andriessen P, Renier WO. Epidemiology of pyridoxine dependent seizures in the Netherlands. Arch Dis Child 2005;90:1293-1296.

7. Gospe SM Jr. Pyridoxine-dependent seizures: new genetic and biochemical clues to help with diagnosis and treatment. Curr Opin Neurol 2006;19:148-153.

8. Grillo E, Silva R, Barbato J Jr. Pyridoxine-dependent seizures responding to a extremely low-dose pyridoxine. Dev Med Child Neurol 2001;43: 413-415.

9. Nabbout R, Soufflet C, Plouin P, Dulac O. Pyridoxine dependent epilepsy: a suggestive electroclinical pattern. Arch Dis Child Fetal Neonatal Ed 1996;81:125-129. 